\title{
The Innovation and Practice of the Course of Copywriting in Advertising LiMing Zhang ${ }^{1}$ \\ ${ }^{1}$ Qujing normal university, yunnan qujing city kirin sanjiang avenue, 655011 308053539@qq.com
}

Keywords: The writing of Advertising Copywriting; Course teaching; Innovation; Practice

\begin{abstract}
Advertising copy writing is a major course of advertising major in Colleges and universities. The traditional theory based teaching method can not reflect the practicality, applicability and comprehensiveness of the curriculum, so that students' learning enthusiasm is affected to a certain extent. This article will analyze the teaching methods and methods of the ad writing course, and then think about the innovation and practice of the writing of the copywriting.

The writing of Advertising Copywriting is the main course of advertising majors in many colleges and universities in China. This course is based on the basic courses of advertising science, and it's required to strengthen the writing skills and methods of advertising copy, and create advertising copy works. The writing of advertisement copywriting has the characteristics of application and practice. So the purpose of this course is to ask students based on the advertisement theory learning, writing methods and techniques can fully understand the various types of media advertisement, grasp the process and steps of writing ad copy, which can carry out different kinds of text creation, at the same time, to strengthen the students' writing ability in the text creation exercise.
\end{abstract}

How to make students more interested in writing courses, more acceptable curriculum knowledge, but also consciously strengthen the copy writing, in order to improve their writing ability, the creation of excellent works copy problem is put need to think and solve the issue in front of advertisement writing teachers. Through the long term teaching practice of the ad writing course, it is believed that it is necessary to attach importance to the innovation and practice of the teaching methods and means of this course. Through the innovation and practice of teaching contents, teaching methods and means, and improving the art of teaching, students can truly sit, listen, learn, and use. In the process of advertising copy writing teaching, teachers should combine the nature and characteristics of the course, and mainly innovate and practice from the aspects of teaching purpose, interest, teaching idea, content, teaching method, homework layout, curriculum assessment and so on.

\section{Clear the Purpose of the Course Teaching and Stimulate the Students' Interest in Learning}

Some students think that as long as the design of excellent advertising works, others are not important, this is a misunderstanding of the understanding. At the beginning of the program, through class discussion and copy the case of appreciation and other ways to help students understand the purpose of teaching the course, students should be aware of outstanding advertising works formed in addition to the design elements, the advertisement is indispensable, is one of the means to achieve the goal of advertising; a good advertising division must have the necessary copy appreciation and creation ability. At the same time, through the introduction of outstanding advertising copy personas, typical advertising copy case discussion and analysis, we should strengthen classroom wide exchanges and discussions between teachers and students, actively publish their own views, and stimulate students' interest in learning copywriting courses.

\section{Innovation and Practice of Teaching Idea and Content}

As the type of Advertising Copywriting is more and more rich and more diversified, new challenges have been put forward to the theory teaching of copywriting. In the course of teaching, we can not still only stay in the teaching and practice of the simple writing of copywriting, which can not meet 
the needs of the advertising industry and employment. Therefore, in the course of preparation and teaching, we should pay more attention to the updating and supplement of the relevant knowledge points of the copywriting, such as the writing and requirements of the new media. At the same time, it is actively transferred to the students "view of the great case of writing", that is, the copywriting and advertising activities are one. Let students understand and understand the concept of "big copy" step by step in the course of theoretical study, case analysis and creation, and really integrate advertising copywriters and advertising activities, create excellent copywriters, and better achieve the effect of advertising activities. Moreover, we should emphasize that teachers play a guiding role in the course of course learning, and the students are leading, strengthening the students' leading consciousness, and supervising and checking the students' self-study. There are certain contents in each chapter that require students to learn themselves after class and cultivate their students' ability to study independently.

\section{Attaching Importance to the Innovation and Practice of Teaching Methods}

"The teaching method is the concrete way to realize the teaching goal and the training principle." Under the guidance of the concept of large copy, we need to enlarge copywriting to a large advertising campaign environment. We need to vividly explain and analyze the whole process of advertising campaign, and change theory into practice, stimulate interest by interactive discussion. [1]In the past, the main course of was classroom teaching, and the creation and practice were left after class. In this way, the learning of classroom theoretical knowledge is relatively dull, and students are not interested in it. There is a lack of concentration. At the same time, the initiative of after-school writing is not strong enough, or even just to cope with it, which leads to the fact that theory and practice cannot be well integrated. In the innovation and practice of teaching methods, we should intensify the combination of theory and practice, and actively try such teaching methods as collection and sharing, teamwork, case simulation and collective mutual evaluation in teaching, or even the combination of various teaching methods.

Specific measures: first, we should actively guide students to collect a lot of relevant information and read copywriting works, and check the students' reading situation through classroom sharing and writing notes. Secondly, team work is used to divide class students into small teams, arrange case analysis and corresponding writing tasks, let team members unite and cooperate, promote communication and enhance team consciousness. Third, the use of case simulation method, select the classic case in the classroom analysis and discussion. And the students are required to be creative and form a copywriting according to the previous analysis and their understanding. Then compare the original works with the students' works, find out the advantages and disadvantages, and promote the improvement of students' creative ability. Fourth, the method of correcting the homework is also changed. Change the original way of correcting teachers mainly, but to enter the method of collective evaluation. The teacher according to the different media such as newspaper advertising copy, copy type magazine advertising, radio advertising, television advertising, advertising copywriting, writing assignments accordingly, students of each operation submitted after the use of class time for students to exchange some articles in the review requirements and find the advantages and shortcomings, write comments their ideas in order to provide reference to students, at the same time, teachers on the basis of this once again review, revision, summary and comment. This method helps students to communicate and interact with each other and learn from each other to complement each other. Fifth, the creation of practice methods such as diversification, classroom exercises and after-school creative combination; collective creation, embodies teamwork; encourage students to participate in various competitions such as advertising contest, national computer application skills competition, with the game to test and improve students' writing ability, greatly enhance the enthusiasm and initiative of students learning and creation the.

\section{Improving Scientific Research Ability and Strengthening Teaching Research}

In order to cultivate students into excellent copywriters, teachers should not only rely on classroom 
teaching and copywriting practice. The group members should be used more actively to discuss collective meetings, courses and advertising related content to communicate, discuss and study, "a positive declaration of key courses, courses, published paper, write more practical advertising copy writing materials, through innovative research teaching to promote the teaching content and teaching mode." [2] promotes its scientific research ability, and realizes the aim of promoting teaching by teaching and research. At the same time, active and student participation in various advertising and copywriting competitions, giving students more professional guidance, so that teachers and students grow together in practice.

\section{Making Full Use of Network Resources}

In order to enrich the writing content of classroom teaching, to stimulate students interest in learning, teachers will carefully designed courses copy electronic courseware and courseware, the specific teaching contents and classic copywriting case with images, sound and animation and other visual and auditory elements, with the help of multimedia equipment to show to the students, so as to enhance classroom teaching copywriting intuitive and artistry. To arouse the students' interest in writing.

It is necessary to make full use of multimedia teaching in the writing of copywriting, so that it will become the normal course of the course. First of all, the main use of PPT for teaching. Before class, the teaching content will be made into a relatively intuitive, vivid, beautiful and vivid teaching courseware, and integrated into video (TV advertising) and audio (radio advertising), making PPT content richer. The second is to collect outstanding ads, radio advertising, television broadcasting, copywriting, provide show students appreciation and discussion, not only enrich the teaching content, active classroom atmosphere, enhance classroom teaching copywriting intuitive and artistic, and stimulate students' learning interest in writing, but also enhance the students copywriting appreciation and analysis ability. At the same time, with the emergence of new media, provide better and more open teaching platform for advertisement writing teaching, such as teaching we can "use micro-blog, WeChat and other media platform, micro-blog, WeChat, to create a public number, copywriting practice into a practical exercises, and is no longer empty talk." [3] makes network resources better serve the teaching of Advertising Copywriting.

\section{The Innovation and Practice of the Way of Examination}

The innovation and practice of the examination mode of the ad writing course is mainly to establish a scientific curriculum evaluation standard and try different way of examination. According to the characteristics of the course, the scoring standard of the course is set up, and different methods of correcting the course are tried. At the same time, as a practical course, can be used in different ways such as classroom assessment, examination, separation of teaching and examination, examination, examination, defense works and other forms of Advertising Courses for students to achieve theoretical knowledge and grasp own creation practice ability examination.

Based on the practicality and comprehensiveness of advertising copy writing, the purpose of curriculum assessment is to evaluate students' basic principles, writing skills and copywriting skills of various communication carriers. Therefore, the assessment method should be more appropriate to reflect the characteristics and characteristics of the copywriting course. On the advertising copy writing, compared to theoretical courses by the final examination assessment methods can not fully reflect the students' ability of the documents about the course of writing skills and learn the integrated use of problem-solving skills, so try to carry on the corresponding reform of curriculum examination and innovation, such as the abolition of the final examination. The skills assessment mainly consists of two parts, students copy writing and final copy works and statements, the course final grade will be composed of students copy works, works statement comprehensive score. In order to highlight the advertisement writing practice and skill assessment characteristics, students usually more seriously learning writing skills and strengthen advertising creation training, change in order to test and cram the passive learning situation, improve students' learning initiative, cultivate 
students' comprehensive ability, problem solving, creative writing skills to master.

\section{Conclusion}

Advertising copy writing because of its advertising profession in belong to the main course, it has the characteristics of practicality and applicability, teachers in the teaching, should be in the advertising specialty training programs and curriculum syllabus requirements, through the advertisement writing curriculum objectives, teaching ideas, teaching methods, teaching and scientific research, cyber source, examination reform and other aspects of the course curriculum construction, innovation and practice, in order to improve the students writing ability of advertising, advertising to enhance professional skills of students.

\section{Acknowledgements}

Fund Project: High quality curriculum construction project of Qujing Normal University (YZKC2016001)

\section{Reference}

[1] H. Zhao: On the Innovation of Advertising Talents Training Mode from the Teaching Reform of Advertisement Copywriting Course,(2012) No.3, p.135-137. (In Chinese)

[2] L.L. Zheng: Discussion on the Teaching Reform of Copywriting in Advertising,(2010) No.11, p.107-108. (In Chinese)

[3] Y.H. Lin: On the Shift of Center of Gravity of Advertising Copywriting in the Era of Media, (2016) No.34, p.172. (In Chinese)

[4] Peng L. Cost heterogeneity and peak prediction in collective actions [J]. Expert Systems With Applications, 2017, 79: 130-139. 